\title{
Langerhans Cell Histiocytosis as Cause of Central Diabetes Insipidus: Case Report
}

\section{Histiocitose de células de Langerhans como causa de diabetes insípido central: relato de caso}

\author{
Diana Quirino Nascimento $^{1}$ Manoel Jacobsen Teixeira ${ }^{1} \quad$ Eberval Gadelha Figueiredo ${ }^{1}$ \\ ${ }^{1}$ Division of Neurosurgery, Medical School - Faculdade de Medicina, \\ Universidade de São Paulo, São Paulo, SP, Brazil \\ Arq Bras Neurocir 2018;37:76-79. \\ Address for correspondence Diana Quirino Nascimento, Medical \\ Student, Faculdade de Medicina da Universidade de São Paulo, \\ Av. Dr. Arnaldo, 455 - Cerqueira César, São Paulo, SP, 01246-903, Brazil \\ (e-mail: diana.nascimento@fm.usp.br).
}

\section{Abstract \\ Keywords \\ - histiocytosis \\ - Langerhans cell \\ - pituitary gland \\ - hypothalamo- hypophyseal system \\ - diabetes insipidus}

\section{Resumo}

Langerhans cell histiocytosis ( $\mathrm{LCH}$ ) is a rare disease of the monocyte-macrophage system, characterized by the aberrant proliferation of specific dendritic cells. The clinical presentation ranges from a single bone lesion to widespread multiorgan involvement. This disease is usually considered to be a disease of childhood; however, the diagnosis is frequently made in adulthood. The course of the disease is fairly unpredictable and varies from spontaneous resolution to progress into a debilitating form, which compromises the vital functions with occasional fatal consequences. Langerhans cell histiocytosis exhibits a predilection for the hypothalamic-pituitary-axis, with diabetes insipidus being the most common endocrine consequence related to the disease, which may be prior to diagnosis or develop at any time during the course of the disease. The diagnosis of LCH should be based on histologic and immunophenotypic examination of a lesional biopsy, although other testing may be done, depending on the symptoms. There is no established, widely agreed-upon treatment of $\mathrm{LCH}$, in general. The treatment depends upon the individual patient and the extent and areas of involvement. The present article aims to describe the case of a 26-year-old male patient whose symptoms started with a headache and occipital bone lesion that progressed later with diabetes insipidus.

A histiocitose de células de Langerhans ( $\mathrm{HCL}$ ) é uma rara doença do sistema monocítico-macrofágico, caracterizada pela proliferação aberrante de células dendríticas específicas. As manifestações clínicas variam de uma única lesão óssea a um acometimento extenso de múltiplos órgãos. Esta doença geralmente é considerada uma doença da infância; no entanto, o diagnóstico é frequentemente feito na idade adulta. O curso da doença é bastante imprevisível e varia de resolução espontânea a progressão para uma forma debilitante, com comprometimento de funções vitais e ocasionais consequências fatais. A HCL exibe uma predileção pelo eixo hipotálamohipofisário, sendo o diabetes insípido a consequência endócrina mais comum received

November 29, 2017

accepted

January 8, 2018

published online

March 19, 2018
DOI https://doi.org/

10.1055/s-0038-1639499. ISSN 0103-5355.
Copyright $\odot 2018$ by Thieme Revinter

Publicações Ltda, Rio de Janeiro, Brazil
License terms

(c) $(1) \$$ 


\section{Palavras-chave}

- histiocitose de células de Langerhans

- hipófise

- sistema hipotálamohipofisário

- diabetes insípido relacionada à doença, podendo ser anterior ao diagnóstico ou se desenvolver a qualquer momento durante o curso da doença. O diagnóstico de $\mathrm{HCL}$ deve basearse nos exames histológico e imunofenotípico de uma biópsia lesional, embora outros exames possam ser feitos a depender dos sintomas apresentados pelo paciente. Não existe um tratamento estabelecido, amplamente aceito para a $\mathrm{HCL}$, em geral. $\mathrm{O}$ tratamento depende individualmente do paciente, da extensão e das áreas de envolvimento. $O$ presente artigo tem como objetivo descrever o caso de um paciente do sexo masculino de 26 anos de idade que iniciou o quadro com uma cefaleia e lesão óssea occipital que evoluiu posteriormente com quadro de diabetes insípido.

\section{Introduction}

Langerhans cell histiocytosis (LCH) is a rare disease of the monocyte-macrophage system characterized by the aberrant proliferation of specific dendritic cells. ${ }^{1,2}$ Histiocytic disorders are a group of diseases that occur when there is an over-production of white blood cells, known as histiocytes, that can lead to organ damage and tumor formation. ${ }^{3}$ This group is made up of a wide variety of conditions that can affect both children and adults.

Langerhans cell histiocytosis is a rare and enigmatic clonal disorder that affects mainly children. It is characterized by single or multiple granulomatous mass lesions composed of cells with the Langerhans' cell phenotype. ${ }^{4}$ The clinical presentation and behavior are heterogeneous and can range from a solitary lytic bone lesion with a favorable course to a disseminated form. Although LCH typically involves the bone, lesions can be found in almost all organs. ${ }^{4}$ It is also possible to have $\mathrm{LCH}$ in a particular location without symptoms. ${ }^{3}$

Langerhans cell histiocytosis commonly affects the central nervous system (CNS). However, rarely is this the only site. The most common CNS locations involved are the hypothalamicpituitary-axis and the cerebellum. Diabetes insipidus (DI)is the most common endocrine manifestation of $\mathrm{LCH}^{5}$

Diabetes insipidus is a rare disorder that can occur because of histiocytosis involving the pituitary gland. It is believed that approximately between 5 and $50 \%$ of LCH patients develop DI depending on the extent of disease. ${ }^{6}$

Based on the existence of this association, as well as its importance, the article aims to report the case of a patient diagnosed with LCH that presented manifestations compatible with DI.

\section{Case Report}

A 26-year-old male patient sought medical service complaining of an occipital headache for 3 months. Physical examination revealed no alterations; however, the occipital region was painful under palpation. A computed tomography (CT) scan of the skull was performed, showing an osteolytic lesion in the occipital region.

From this finding, a biopsy and complete excision of the lesion were performed, with remission of the headache, and no type of medication was prescribed. The biopsy result was inconclusive. A full-body CT scan was performed, which did not indicate any relevant finding or possible metastatic focus.

After eight months of the beginning of the follow-up, he began to present episodes of vomiting and lowering of the level of consciousness. He sought the emergency room, where he was found to have hypernatremia, with sodium of $160 \mathrm{mEq} / \mathrm{L}$. A magnetic resonance imaging (MRI) was then performed, depicting a lesion on the hypothalamic-pituitarythalamic axis that was suggestive of LCH ( - Figs. 1, 2, 3, 4). Thus, we proposed the diagnosis of DI as a result of $\mathrm{LCH}$.

The treatment offered by the oncology team was performed using a steroid, $4 \mathrm{mg} /$ day, with good remission of the lesion after 6 months. In the evolution, the patient presented findings of panhypopituitarism; he is currently receiving hormone replacement and being followed up in an outpatient clinic.

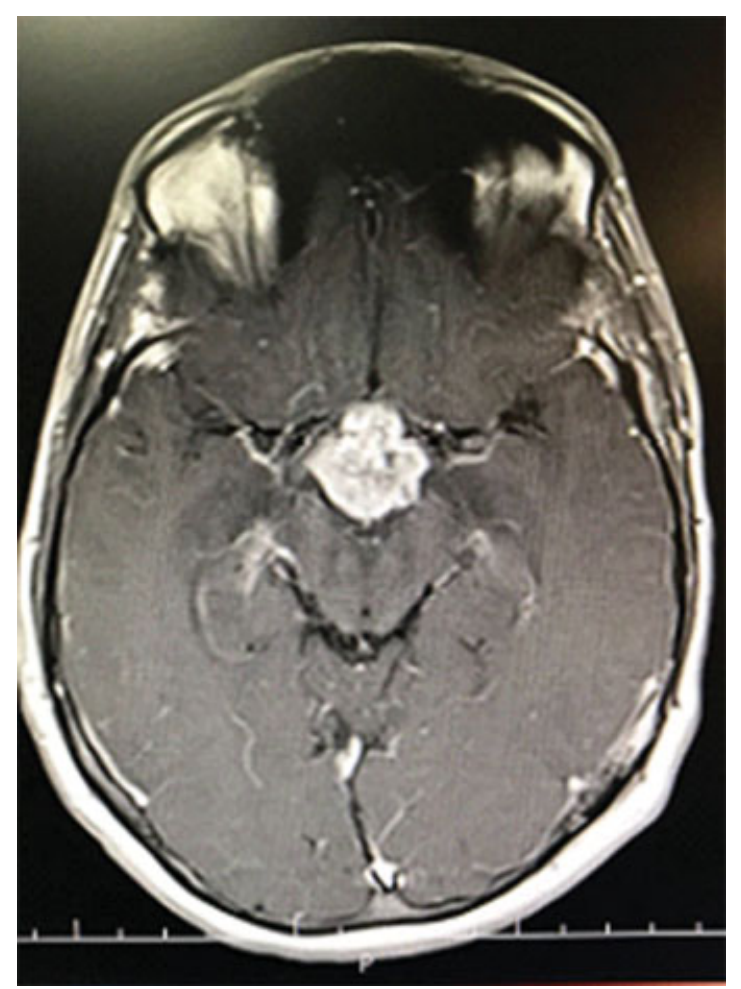

Fig. 1 T1-weighted magnetic resonance imaging after contrast injection, showing lesion compatible with Langerhans cell histiocytosis in the hypothalamic-pituitary-axis topography. Axial section. 


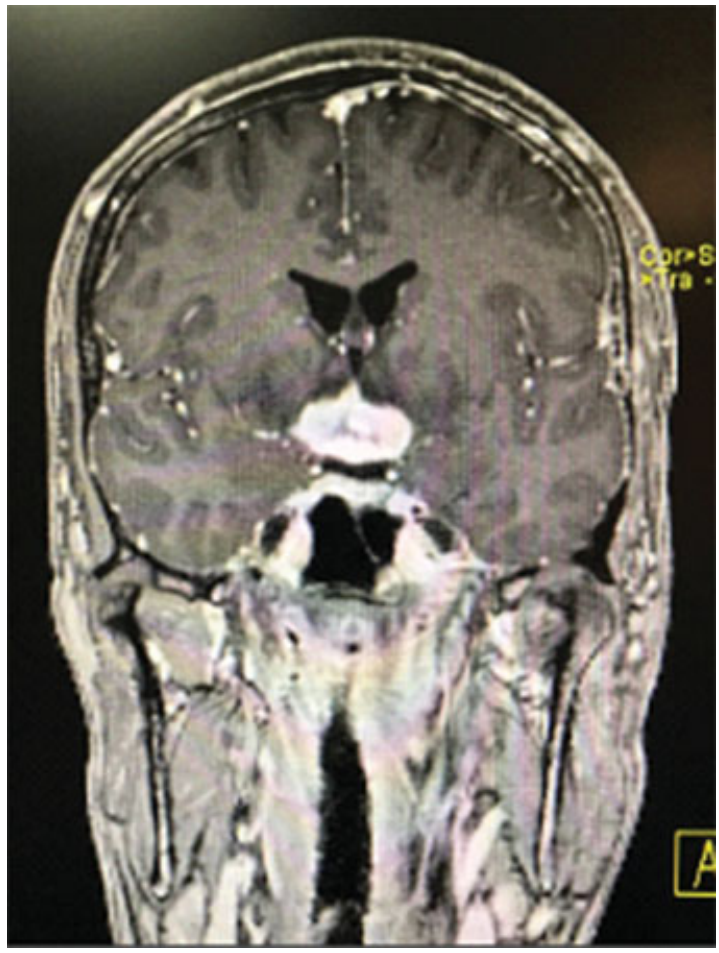

Fig. 2 T1-weighted magnetic resonance imaging after contrast injection, showing lesion compatible with Langerhans cell histiocytosis in the hypothalamic-pituitary-axis topography. Coronal section.

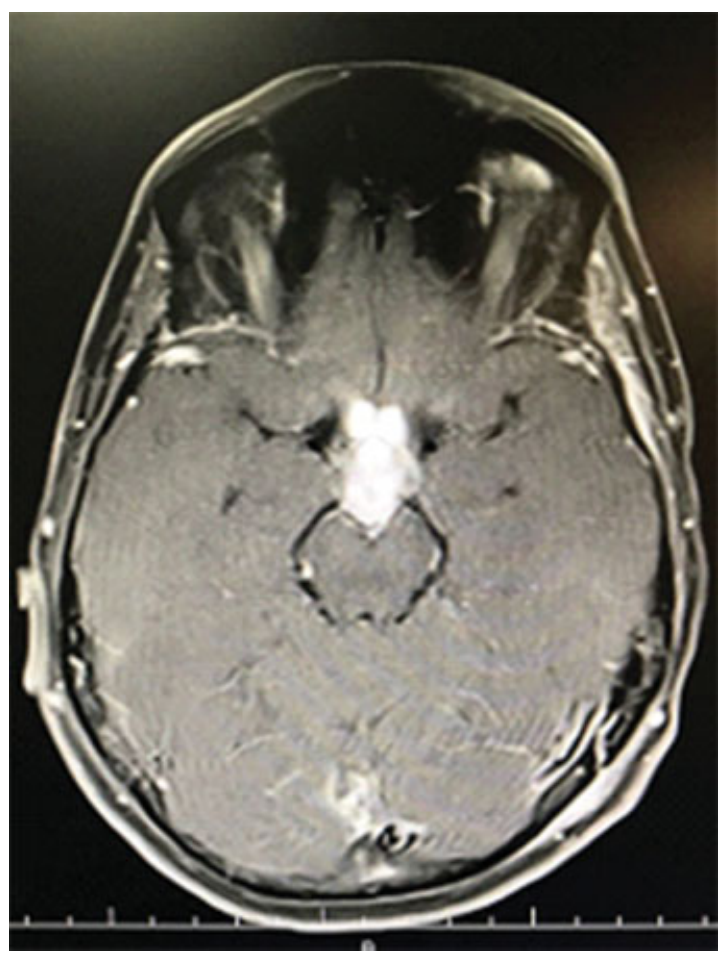

Fig. 3 Another axial T1 - weighted MRI scan showing lesion compatible with Langerhans Cell Histiocytosis in the Topography of the hypothalamic-pituitary-axis.

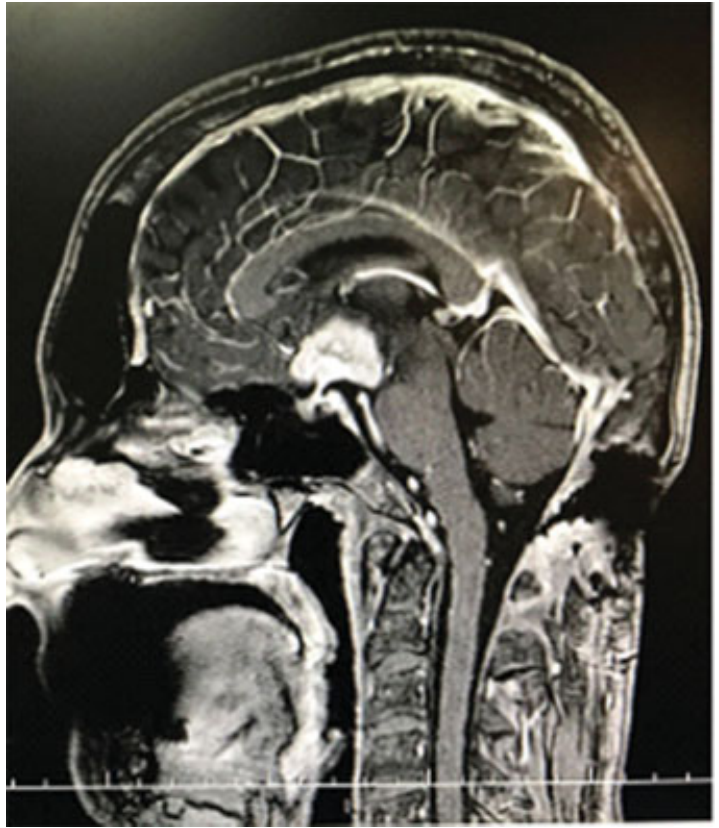

Fig. 4 T1-weighted magnetic resonance imaging after contrast injection, showing lesion compatible with Langerhans cell histiocytosis in the hypothalamic-pituitary-axis topography. Sagittal section.

\section{Discussion}

In 1987, the Histiocyte Society classified these disorders into three groups based on the types of histiocyte cells involved ${ }^{3}$ :

- Group 1: is called a dendritic cell disorder, and Langerhans cell histiocytosis (HCL) is the most common disease in this group. Also included in this group are rarer diseases, such as juvenile Xanthogranuloma and Erdheim-Chester disease.

- Group 2: is called a macrophage cell disorder and includes primarily hemophagocytic lymphohistiocytosis (HLH) and Rosai-Dorfman (RD) disease.

- Group 3: is called malignant histiocytosis and includes certain kinds of leukemia and malignant tumors.

Langerhans cell histiocytosis is a heterogeneous disease, characterized by the accumulation of dendritic cells with features similar to epidermal Langerhans cells in various organs. ${ }^{7}$ The clinical and radiologic presentations of LCH are variable and range from a lytic skeletal lesion, incidentally seen at radiography, to widespread disease with severe organ dysfunction. $^{5}$ In recent years, there has been increasing evidence to support the idea that LCH is a "neoplasm," which means that LCH tumors contain cells with gene mutations that cause them to make copies of themselves inappropriately. ${ }^{8}$ There is a specific gene called $B R A F$ that has a mutation in about one half of LCH tumors. ${ }^{8}$ Recent research has identified other genes with mutations in LCH lesions, but this requires further research.

Langerhans cell histiocytosis is most frequently found in children and has different clinical characteristics in adults and children; skin, lung and bone involvement and DI are common manifestations with adult $\mathrm{LCH}$, whereas the 
involvement of the liver, spleen, lymph nodes and bone marrow is much less frequent. ${ }^{2}$

Langerhans cell histiocytosis can affect any organ or system of the human body, but those more frequently involved are the skeleton ( $80 \%$ of cases), the skin (33\%), and the pituitary (25\%). Other organs involved are the liver, spleen, the hematopoietic system and the lungs (15\% each), lymph nodes (5-10\%), and the CNS, excluding the pituitary (2-4\%). ${ }^{7}$

Langerhans cell histiocytosis exhibits a predilection for the hypothalamo-pituitary region, leading to permanent posterior and/or anterior pituitary hormonal deficiencies in a subset of patients. Diabetes insipidus is the most common disease-related consequence that can predate the diagnosis or develop anytime during the course of the disease. Diabetes insipidus is found in up to $30 \%$ of patients, but may reach to $40 \%$ in patients with multisystem disease, or $94 \%$ in the presence of other pituitary deficiencies. ${ }^{9}$

The diagnosis of LCH should be based on histologic and immunophenotypic examination of a lesional biopsy. Normal Langerhans cells stain positively with CD1a and/or Langerin. ${ }^{9}$ If the biopsy is positive for $\mathrm{LCH}$, some other tests may be performed to determine the extent of the disease so that a treatment plan can be made. These may include skeletal X-ray survey with skull X-ray series, bone scan, blood tests, and urine tests. ${ }^{8}$ If there are symptoms of DI, as in the case of the patient of this report, a water-deprivation test should be done. When the bones near the ears or eyes are involved, a head CT scan is indicated. An MRI of the brain may be necessary if the lesions are near the eyes or ears or there is suspicion of CNS involvement. ${ }^{8}$ Other testing may be done, depending on the symptoms. Other biopsies may be performed if test results or abnormal findings during the physical exam cause the physician to suspect involvement of another area.

Magnetic resonance imaging findings in central DI are characterized by lack of high signal intensity of the posterior pituitary on T1-weighted images, which is often associated with enhancement and thickening of the pituitary stalk of more than $3 \mathrm{~mm} .{ }^{5}$ However, the posterior pituitary bright spot frequently persists in patients with DI; therefore, it is not a very reliable characteristic. ${ }^{5}$

There is no established, widely agreed-upon treatment of $\mathrm{LCH}$, in general. The treatment depends upon the individual patient and the extent and areas of involvement. Some patients have had success with vinblastine (chemotherapy) and steroids, while others have benefited from limited surgery and other chemotherapy agents such as 2-chlorodeoxyadenosine $(2 \mathrm{CdA})$ or methotrexate, and even low-dose external beam irradiation. ${ }^{8}$ Some patients may have limited involvement, which does not progress to other areas and may not need systemic treatment.
Langerhans cell histiocytosis may reactivate and lead to chronic local symptoms or induce organ dysfunction. Rarely LCH is associated with malignant tumors. Therefore, followup investigations of the disease and monitoring of functional impairments are necessary. ${ }^{9}$

\section{Conclusion}

Langerhans cell histiocytosis may present a wide variety of clinical symptoms and manifestations, depending on factors such as site of involvement, individual features and extent of lesions. In addition, it is also possible to develop LCH in a specific location without presenting symptoms. Thus, the diversity of manifestations together with the relative rarity of the disease may make it difficult to perform the clinical diagnosis.

However, the possibility of more serious and even fatal complications highlights the need for $\mathrm{LCH}$ to be considered as a differential diagnosis in medical practice and for the investigation to be done adequately to favor early diagnosis.

\section{References}

1 Grois N, Fahrner B, Arceci RJ, et al; Histiocyte Society CNS LCH Study Group. Central nervous system disease in Langerhans cell histiocytosis. J Pediatr 2010;156(06):873-881, 881.e1

2 Srivanichakorn W, Tanboon J, Sriwijitkamol A. Langerhans Cell Histiocytosis: A Rare Cause of Central Diabetes Insipidus. Internal Medicine: Open Access. 2012;2(01):. Doi: 10.4172/2165-8048.1000107

3 Histiocytic Disorders. Histiocytosis Association 2017. Available from: https://www.histio.org/page.aspx?pid=378\#.Whgx8kqnGM-. Accessed: 2017 (jul 15)

4 Scolozzi P, Lombardi T, Monnier P, Jaques B. Multisystem Langerhans' cell histiocytosis (Hand-Schüller-Christian disease) in an adult: a case report and review of the literature. Eur Arch Otorhinolaryngol 2004;261(06):326-330

5 D'Ambrosio N, Soohoo S, Warshall C, Johnson A, Karimi S. Craniofacial and intracranial manifestations of langerhans cell histiocytosis: report of findings in 100 patients. AJR Am J Roentgenol 2008;191(02):589-597

6 Diabetes Insipidus. Histiocytosis Association 2017. Available from: https://www.histio.org/page.aspx?pid=407\#. WhgyvkqnGM9. Accessed: 2017 (sep 19)

7 Haupt R, Minkov M, Astigarraga I, et al; Euro Histio Network. Langerhans cell histiocytosis (LCH): guidelines for diagnosis, clinical work-up, and treatment for patients till the age of 18 years. Pediatr Blood Cancer 2013;60(02):175-184

8 LCH in Adults. Histiocytosis Association 2017. Available from: https://www.histio.org/page.aspx?pid=383\#.WhgzD0qnGM9. Accessed: 2017 (sep 19)

9 Girschikofsky M, Arico M, Castillo D, et al. Management of adult patients with Langerhans cell histiocytosis: recommendations from an expert panel on behalf of Euro-Histio-Net. Orphanet J Rare Dis 2013;8:72 